\title{
Inhibin production by bovine ovarian tissues in vitro and its regulation by androgens
}

\author{
K.M. Henderson $\dagger$ and P. Franchimont* \\ Department of Biochemistry, University of Western Australia, Nedlands, Western Australia, 6009 \\ and ${ }^{*}$ Laboratoire de Radioimmunologie, C.H.U. Institut de Pathologie-B.23, Université de Liège, \\ Belgium
}

\begin{abstract}
Summary. No detectable amounts of inhibin were produced by cultured ovarian stroma or luteal tissue. Follicular tissue produced inhibin in vitro and removal of the granulosa cells from the follicle wall caused inhibin production to fall by $80 \%$. Granulosa cells alone had the greatest ability of any ovarian cell type to produce inhibin in vitro, and are probably the major site of follicular inhibin production.

Cyproterone acetate at concentrations of 35 and $350 \mu \mathrm{M}$ inhibited basal and testosterone ( $3.5 \mu \mathrm{M})$-stimulated inhibin production by cultured intact follicle wall and granulosa cells. In addition, each concentration of cyproterone acetate inhibited progesterone but not oestradiol-17 $\beta$ production by the follicle wall and granulosa cell cultures. The synthetic, non-aromatizable androgens, methylestrenolone and mesterolone, at concentrations of 5 and $25 \mu \mathrm{M}$, mimicked the effect of testosterone and stimulated granulosa cell inhibin production, methylestrenolone being the more potent. These findings provide further evidence that androgens regulate follicular inhibin and progesterone production and that these may be receptor-mediated processes, and suggest that inhibin production may be a general property of androgenic compounds.

Preliminary examination of the physicochemical characteristics of inhibin indicated that the inhibin activity of bovine granulosa cell culture medium was (a) retained by an Amicon XM100A filter with a nominal molecular weight cut-off point of 100000 ; and (b) destroyed by heating to $80^{\circ} \mathrm{C}$ for $30 \mathrm{~min}$.
\end{abstract}

\section{Introduction}

There is increasing evidence to indicate that inhibin produced by the ovary is physiologically important in the regulation of pituitary FSH secretion, and consequently follicular development (Franchimont et al., 1979, 1981; Henderson \& Franchimont, 1981). Follicular granulosa cells secrete inhibin in vitro (Erickson \& Hsueh, 1978; Anderson \& de Paolo, 1981; Henderson \& Franchimont, 1981) and are therefore considered to be the site of ovarian inhibin production. However, little information is available on the ability of other ovarian cell types to produce inhibin. The purpose of this study was to compare the relative efficiency of intact bovine follicular tissue, isolated thecal tissue and granulosa cells, and ovarian stromal and luteal tissue to produce inhibin in vitro. In addition, in view of the finding that androgens may regulate ovarian inhibin production (Henderson \& Franchimont, 1981), the effects on inhibin production of the anti-androgen, cyproterone acetate, and the synthetic androgens, mesterolone and methylestrenolone, were studied. A preliminary examination of the physicochemical characteristics of ovarian inhibin produced in vitro was also undertaken.

†Present address: Wallaceville Animal Research Centre, Private Bag, Upper Hutt, New Zealand. 


\section{Materials and Methods}

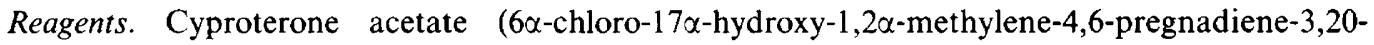
dione-17-acetate) and mesterolone (17 $\beta$-hydroxy-l $\alpha$-methyl-5 $\alpha$-androstan-3-one) were obtained from Schering A.G., Berlin. Methylestrenolone (17 $\beta$-hydroxy-17-methylestr-4-en-3-one) was obtained from Organon, Oss, Holland. All other steroids were obtained from Sigma (London) Chemical Co. Ltd, Poole, Dorset, U.K.

Cell and tissue culture. Ovaries were obtained from healthy adult cows within $1 \mathrm{~h}$ of their slaughter at a local abattoir. Antral follicles present on the surface of the ovary and containing $\geqslant 0.3$ $\mathrm{ml}$ follicular fluid ( $\geqslant 10 \mathrm{~mm}$ diameter) were dissected out and trimmed free of adhering tissue. Follicular fluid was aspirated by syringe and needle, and the collapsed follicle was slit open and bissected. One half was used for cultures of intact follicle wall. Granulosa cells were removed from the other half of the follicle wall by scraping with a platinum wire loop. The cells were collected into Eagle's Minimum Essential Medium (modified) with Earle's salts (Eagle, 1959) supplemented with Hepes buffer (20 mM), glutamine ( $2 \mathrm{mM}$ ), penicillin ( 50 units $/ \mathrm{ml})$, streptomycin $(50 \mu \mathrm{g} / \mathrm{ml})$, amphotericin B $(2.5 \mu \mathrm{g} / \mathrm{ml})$ and non-essential amino acids (Eagle, 1959). (All reagents obtained from Flow Laboratories, Irvine, U.K.) After washing twice with the above medium, the cells were counted in a haemocytometer, and their viability was determined by uptake of nigrosin dye. Representative portions of the intact follicle wall, and the follicle wall remaining after the granulosa cells had been removed were taken for histological examination. The follicle wall minus granulosa cells was termed thecal tissue and cultured as such, although histological examination showed that considerable amounts of stromal tissue were also present. Using scalpel blades, minces were prepared of the intact follicle wall and thecal tissues, and from samples of ovarian stroma and corpus luteum. Aliquants of these minces corresponding to 1-2 mg protein, and a minimum of $1 \times$ $10^{5}$ 'live' granulosa cells were cultured separately in multi-welled tissue-culture Petri dishes (Sterilin, Middlesex, U.K.) at $37^{\circ} \mathrm{C}$ in $1 \mathrm{ml}$ of the above medium containing $10 \%$ newborn calf serum (Commonwealth Serum Laboratories, Melbourne, Australia). The gas phase was air. Steroids were added to the cultures in ethanol (testosterone, mesterolone and methylestrenolone) or methanol (cyproterone acetate). Control cultures received vehicle alone. The concentration of organic solvent in the culture medium never exceeded $1 \%$. Aliquants of the tissue minces and granulosa cells were also taken to determine the endogenous concentrations of inhibin and steroids. These samples were homogenized in $1 \mathrm{ml}$ culture medium, which was then freeze-dried and assayed for inhibin, or in $1 \mathrm{ml}$ ethanol which was then assayed for steroids. After culture for $24 \mathrm{~h}$, the medium was removed and aliquants taken and freeze-dried for subsequent inhibin determination while the remainder was stored frozen until assayed for steroids. The granulosa cells and tissue fractions were washed thoroughly with medium devoid of serum. The granulosa cells were stored frozen until assayed for protein by the method of Lowry, Rosebrough, Farr \& Randall (1951) as modified by Patterson (1979). The tissue fractions were taken up in $1 \mathrm{ml}$ of $1 \mathrm{M}$-sodium hydroxide and assayed for protein by the method of Lowry et al. (1951). Inhibin and steroid production by the ovarian tissues was calculated by subtracting the values obtained for the endogenous tissue concentrations of inhibin and steroid from those present in the culture medium after the 24-h culture period.

Inhibin assay. Inhibin activity was determined using a bioassay based on the inhibition of LHRH-stimulated FSH secretion by cultured rat anterior pituitary cells as described and validated by Henderson \& Franchimont (1981). The freeze-dried aliquants of cell culture medium taken for inhibin assay were reconstituted with distilled water. Steroids were removed by mixing for $16 \mathrm{~h}$ at $4^{\circ} \mathrm{C}$ with activated charcoal (Norit A, $1 \%$ pretreated with dextran $(0 \cdot 1 \%)$ followed by centrifugation at $3000 \mathrm{~g}$ (Henderson \& Franchimont, 1981). The supernatants were filter-sterilized by passing through a $0.45 \mu \mathrm{m}$ cellulose millipore filter before use. Aliquants were then tested for their ability to inhibit LH-RH $\left(10^{-8} \mathrm{M}\right)$-stimulated FSH secretion by cultured rat anterior pituitary cells during a 6-h incubation period. Inhibin activity of the cell culture medium was expressed 
relative to the potency of a standard reference preparation of inhibin derived from ovine testicular lymph which has been designated an arbitrary potency of $1 \mathrm{U} / \mathrm{mg}$ (Eddie, Baker, Higginson \& Hudson, 1979). Regression analysis and parallel line assay statistics (Borth, 1976) were used to relate the inhibin activity of the culture medium to that of the inhibin standard.

Radioimmunoassays. The gonadotrophin concentrations in media from the pituitary cell cultures were measured in duplicate by double-antibody methods using NIAMDD rat pituitary gonadotrophin reagents supplied by the pituitary agency of NIH. The concentrations were expressed in terms of NIAMDD rat-FSH-RP1 and rat-LH-RP1. The sensitivities of the assays were $5 \mathrm{ng} \mathrm{FSH} / \mathrm{ml}$ and $10 \mathrm{ng} \mathrm{LH} / \mathrm{ml}$. The inter- and intra-assay coefficients of variation were 3 and $8 \%$ for the FSH assay and 5 and $12 \%$ for the LH assay respectively.

Steroid concentrations in the cell culture medium and ethanolic extracts of the ovarian tissues were determined using the specific radioimmunoassays described previously (McNatty, Gibb, Dobson, Thurley \& Findlay, 1981). The limit of sensitivity of the assays (per tube) was $25 \mathrm{pg}$ for progesterone, $5 \mathrm{pg}$ for oestradiol- $17 \beta$ and $10 \mathrm{pg}$ for testosterone. The intra- and inter-assay coefficients of variation were each $<10 \%$ and $<16 \%$ respectively.

Fractionation of bovine granulosa cell culture medium. Granulosa cell culture medium was fractionated by filtering consecutively through XM100A, XM50 and PM10 Amicon filter membranes (Amicon Ltd, Massachusetts, U.S.A.). These filters have nominal molecular weight cutoff points of $>100000,>50000$ and $>10000$ respectively. Aliquants of each filtrate and retentate were assayed for protein (Lowry et al., 1951) and inhibin activity.

Statistics. Unless otherwise stated, the statistical significance of observed differences between different treatment groups was determined by analysis of variance in conjunction with Fisher's least significant difference test. When Bartlett's test indicated heterogeneity of variance, data were transformed to logarithms to equalize the variances before statistical analysis. The level of significance was set at $P<0.05$.

\section{Results}

Inhibin production by various ovarian cell types

Table 1 shows that, under both basal and testosterone stimulated conditions, only follicular tissue produced inhibin in vitro, and that granulosa cells were the most active cell type. Removal of granulosa cells from the intact follicle wall to leave a thecal shell caused inhibin production to fall by $80 \%$. Oestradiol- $17 \beta$ production by thecal tissue was $<2 \%$ of that produced by the intact follicle wall. No detectable amounts of inhibin or oestradiol- $17 \beta$ were present in the homogenates of ovarian stroma and luteal tissue, or produced by these tissues during culture for $24 \mathrm{~h}$. Although

Table 1. Inhibin and oestradiol-17 $\beta$ production by bovine ovarian tissues cultured for $24 \mathrm{~h}$

\begin{tabular}{lccc}
\hline $\begin{array}{c}\text { Tissue } \\
\text { cultured }\end{array}$ & $\begin{array}{c}\text { Testosterone } \\
(1 \mu \mathrm{g} / \mathrm{ml}) \text { present }\end{array}$ & $\begin{array}{c}\text { Oestradiol-17 } \\
(\mathrm{ng} / \mathrm{mg} \text { protein })\end{array}$ & $\begin{array}{c}\text { Inhibin } \\
(\mathrm{U} / \mathrm{mg} \text { protein })\end{array}$ \\
\hline $\begin{array}{l}\text { Follicle wall } \\
\text { (theca }+ \text { granulosa) }\end{array}$ & - & $6 \cdot 4 \pm 1 \cdot 4^{\mathrm{a}}$ & $26 \pm 1^{\mathrm{a}}$ \\
Theca & + & $8 \cdot 1 \pm 1 \cdot 6^{\mathrm{a}}$ & $54 \pm 2^{\mathrm{b}}$ \\
& - & $0 \cdot 03 \pm 0 \cdot 01^{\mathrm{b}}$ & $4.9 \pm 0 \cdot 3^{\mathrm{c}}$ \\
Granulosa & + & $0 \cdot 13 \pm 0 \cdot 05^{\mathrm{c}}$ & $12 \pm 2^{\mathrm{d}}$ \\
Stroma & - & $\mathrm{ND}$ & $833 \pm 37^{\mathrm{e}}$ \\
Corpus luteum & + & $5300 \pm 520^{\mathrm{d}}$ & $1846 \pm 103^{\mathrm{f}}$ \\
\hline
\end{tabular}

Values are mean \pm s.e.m. for $n=5$. Mean values with different superscripts in the same column are significantly different $(P<0.01)$. ND, not detectable. 
producing small or undetectable amounts of inhibin, the thecal, stromal and luteal tissues seemed functional in vitro. Appreciable amounts of testosterone $(0.8 \pm 0.1 \mathrm{ng} / \mathrm{mg}$ protein) were produced by the thecal tissue, while the luteal and stromal tissues produced $212 \pm 38$ and $0.3 \pm 0.04 \mathrm{ng}$ progesterone/mg protein respectively during the $24-\mathrm{h}$ culture period.

\section{Effect of cyproterone acetate on follicular inhibin and steroid production}

Table 2 shows that cyproterone acetate inhibited testosterone-stimulated inhibin production $(P$ $<0.001)$ and progesterone production $(P<0.001)$ by follicle wall cultured for $24 \mathrm{~h}$. Cyproterone acetate had no effect on oestradial-17 $\beta$ production $(P>0.05)$. Similar results were obtained using granulosa cells in culture (Table 2). Cyproterone acetate inhibited basal $(P<0.01)$ and testosterone-stimulated inhibin production $(P<0.002)$, with the effect being dose-dependent in those cultures receiving testosterone $(P<0.05)$. The inhibition of granulosa cell progesterone production was dose-dependent in the presence and absence of exogenous testosterone $(P<0.001)$. Cyproterone acetate had no effect on the production of oestradiol-17 $\beta(P>0.05)$ which was only detectable in those granulosa cell cultures receiving exogenous testosterone.

Table 2. Effect of testosterone ( $T$ ) and cyproterone acetate (CA) on inhibin production and steroidogenesis by bovine follicle wall or granulosa cells alone cultured for $24 \mathrm{~h}$

\begin{tabular}{|c|c|c|c|}
\hline \multirow{2}{*}{$\begin{array}{l}\text { Additions to } \\
\text { culture medium }\end{array}$} & \multirow{2}{*}{$\begin{array}{l}\text { Inhibin production } \\
(\mathrm{U} / \mathrm{mg} \text { protein })\end{array}$} & \multicolumn{2}{|c|}{ Steroid production ( $\mathrm{ng} / \mathrm{mg}$ protein) } \\
\hline & & Progesterone & Oestradiol-17 $7 \beta$ \\
\hline \multicolumn{4}{|l|}{ Follicle wall } \\
\hline None & $9 \cdot 3 \pm 0 \cdot 6^{a}$ & $15 \cdot 4 \pm 1 \cdot 4^{\mathrm{a}}$ & $3 \cdot 0 \pm 0 \cdot 2^{\mathrm{a}}$ \\
\hline $3 \cdot 5 \mu \mathrm{M}-\mathrm{T}$ & $19 \cdot 4 \pm 1.7^{b}$ & $13 \cdot 0 \pm 1 \cdot 5$ & $4.2 \pm 0.6^{b}$ \\
\hline $35 \mu \mathrm{M}-\mathrm{CA}$ & $9 \cdot 4 \pm 0.6^{\mathrm{a}}$ & $5.1 \pm 0.6^{b}$ & $3.0 \pm 0 \cdot 3^{\mathrm{a}}$ \\
\hline $350 \mu \mathrm{M}-\mathrm{CA}$ & $8 \cdot 8 \pm 0.6^{\mathrm{a}}$ & $3.5 \pm 0.7^{b}$ & $2 \cdot 6 \pm 0 \cdot 1^{a}$ \\
\hline $3.5 \mu \mathrm{M}-\mathrm{T}+35 \mu \mathrm{M}-\mathrm{CA}$ & $12 \cdot 3 \pm 0.3^{\mathrm{c}}$ & $5.5 \pm 0.6^{\mathrm{b}}$ & $4.6 \pm 0.6^{\mathrm{b}}$ \\
\hline $3.5 \mu \mathrm{M}-\mathrm{T}+350 \mu \mathrm{M}-\mathrm{CA}$ & $10 \cdot 9 \pm 0.8^{\mathrm{ac}}$ & $3.3 \pm 0.4^{b}$ & $5 \cdot 1 \pm 0 \cdot 2^{b}$ \\
\hline \multicolumn{4}{|l|}{ Granulosa cells } \\
\hline None & $1050 \pm 44^{a}$ & $1105 \pm 75^{\mathrm{a}}$ & ND \\
\hline $3.5 \mu \mathrm{M}-\mathrm{T}$ & $1600 \pm 87^{b}$ & $1055 \pm 81^{\mathrm{a}}$ & $1376 \pm 182^{a}$ \\
\hline $35 \mu \mathrm{M}-\mathrm{CA}$ & $815 \pm 39^{c}$ & $110 \pm 14^{b}$ & ND \\
\hline $350 \mu \mathrm{M}-\mathrm{CA}$ & $800 \pm 16^{\mathrm{c}}$ & $40 \pm 11^{\mathrm{c}}$ & ND \\
\hline $3.5 \mu \mathrm{M}-\mathrm{T}+35 \mu \mathrm{M}-\mathrm{CA}$ & $1292 \pm 62^{\mathrm{d}}$ & $93 \pm 11^{b}$ & $1519 \pm 96^{\mathrm{a}}$ \\
\hline $3.5 \mu \mathrm{M}-\mathrm{T}+350 \mu \mathrm{M}-\mathrm{CA}$ & $1073 \pm 76^{\mathrm{a}}$ & $37 \pm 7^{c}$ & $1107 \pm 89^{a}$ \\
\hline
\end{tabular}

Values are mean \pm s.e.m., $n=5$. Mean values with different superscripts in the same columns for each tissue type are significantly different, $P<0.05$. ND, not detectable.

\section{Effect of testosterone and synthetic androgens on inhibin and progesterone production by granulosa cells}

Table 3 shows that the synthetic androgens methylestrenolone and mesterolone mimicked the effect of testosterone in stimulating inhibin production by bovine granulosa cells cultured for $24 \mathrm{~h}$ $(P<0.001)$. The stimulatory effects of testosterone and mesterolone were dose-dependent $(P<$ 0.001 and $P<0.05$ respectively) but that of methylestrenolone was not. Methylestrenolone was more active than mesterolone in stimulating inhibin production $(P<0.001)$ and both concentrations of methylestrenolone tested were as active as $5 \mu \mathrm{M}$-testosterone. Methylestrenolone at a concentration of $25 \mu \mathrm{M}$ inhibited progesterone production $(P<0.001)$. Only those cultures receiving testosterone produced detectable amounts of oestradiol-173. The amounts of oestradiol$17 \beta$ produced were (mean \pm s.e.m.) $337 \pm 25$ and $338 \pm 18 \mathrm{ng} / \mathrm{mg}$ protein for the cultures receiving 5 and $25 \mu \mathrm{M}$-testosterone respectively. 
Table 3. Effect of testosterone, methylestrenolone and mesterolone on inhibin and progesterone production by bovine granulosa cells cultured for $24 \mathrm{~h}$

\begin{tabular}{lcc}
\hline $\begin{array}{c}\text { Additions to } \\
\text { culture medium }\end{array}$ & $\begin{array}{c}\text { Inhibin production } \\
\text { (U/mg protein) }\end{array}$ & $\begin{array}{c}\text { Progesterone production } \\
\text { (ng/mg protein) }\end{array}$ \\
\hline None & $196 \pm 9^{\mathrm{a}}$ & $243 \pm 47^{\mathrm{ab}}$ \\
Testosterone & & \\
$\quad 5 \mu \mathrm{M}$ & $607 \pm 11^{\mathrm{b}}$ & $237 \pm 12^{\mathrm{ab}}$ \\
$25 \mu \mathrm{M}$ & $1004 \pm 20^{\mathrm{c}}$ & $255 \pm 19^{\mathrm{a}}$ \\
Methylestrenolone & $629 \pm 12^{\mathrm{b}}$ & $183 \pm 14^{\mathrm{b}}$ \\
$5 \mu \mathrm{M}$ & $643 \pm 17^{\mathrm{b}}$ & $60 \pm 4^{\mathrm{c}}$ \\
$25 \mu \mathrm{M}$ & & \\
Mesterolone & $422 \pm 19^{\mathrm{d}}$ & $261 \pm 19^{\mathrm{a}}$ \\
$5 \mu \mathrm{M}$ & $492 \pm 32^{\mathrm{e}}$ & $232 \pm 18^{\mathrm{ab}}$ \\
$25 \mu \mathrm{M}$ & & \\
\hline
\end{tabular}

Values are mean \pm s.e.m. for $n=5$. Mean values with different superscripts in the same column are significantly different, $P<0.05$.

The above effects of testosterone, cyproterone acetate and the synthetic androgens on inhibin production were not artefacts caused by residual amounts of the test substances, still present after dextran-charcoal treatment of the culture media, modifying FSH production by the cultured pituitary cells in the inhibin bioassay. Dextran-charcoal-treated culture media containing the test substances, but not exposed to granulosa cells or other ovarian tissue, had no effect on pituitary cell FSH production. In addition, measurement of LH-RH in the pituitary cell culture medium throughout the 6-h incubation period indicated that there was no difference in the kinetics of LHRH disappearance in the presence of granulosa cell culture medium whether primed or not with androgen. It is unlikely, therefore, that the androgens were acting to stimulate production of an ovarian peptidase which breaks down LH-RH resulting in reduced FSH production and an apparent increase in inhibin activity.

\section{Physicochemical characteristics of ovarian inhibin}

Fractionation of bovine granulosa cell culture medium (containing $177 \pm 11 \mathrm{U} / \mathrm{mg}$ protein, $n=5$ ) on the basis of molecular size showed that inhibin activity was only present in the retentate after filtration through an Amicon XM100A membrane which has a nominal molecular weight cutoff point of $100000(257 \pm 13 \mathrm{U} / \mathrm{mg}$ protein $n=5 ; P<0.002$, Student's $t$ test). No inhibin activity was present in the $M_{r}<100000$ filtrate, or in the retentates and filtrates following successive filtration of the $\mathrm{M}_{\mathrm{r}}<100000$ filtrate through Amicon XM50 and PM10 membranes with nominal molecular weight cut-off points of 50000 and 10000 respectively. The inhibin activity of granulosa cell culture medium was destroyed by heating to $80^{\circ} \mathrm{C}$ for $30 \mathrm{~min}$.

\section{Discussion}

The present study demonstrates that only ovarian follicular tissue has the ability to produce inhibin in vitro. Ovarian stroma and luteal tissue neither contained nor produced detectable amounts of inhibin. The finding with cultured luteal tissue is similar to that with dispersed luteal cells in culture (Henderson \& Franchimont, 1981). Follicular granulosa cells are probably the major site of ovarian inhibin production. Granulosa cells were the most active cell type with respect to inhibin production in vitro, and removal of granulosa cells from the intact follicle wall to leave a thecal shell 
caused inhibin production to fall to $<20 \%$ of its original value (Table 1 ). The thecal tissue appeared devoid of granulosa cells as assessed by histological examination of representative sections, and by the fact that thecal oestradiol- $17 \beta$ production, under basal and testosterone stimulated conditions, was $<2 \%$ of that produced by the cultures of intact follicle wall (Table 1). Previous studies have indicated that granulosa cells are the principal site of bovine follicular aromatization (Lacroix, Eechaute \& Leusen, 1974). However, in view of the great ability of granulosa cells to secrete inhibin in vitro, the possibility that the thecal inhibin production might be due to residual contaminating granulosa cells cannot be excluded.

Androgens, through their ability to stimulate inhibin secretion, as demonstrated in Table 1, may be involved in the regulation of ovarian inhibin production (Henderson \& Franchimont, 1981). This is supported by the present finding that the anti-androgen, cyproterone acetate, inhibited inhibin production by cultured intact bovine follicular tissue (Table 2). This effect is probably the result of an action on the follicular granulosa cells which are the major source of follicular inhibin. In addition, cyproterone acetate inhibited inhibin production by cultured bovine granulosa cells (Table 2). Cyproterone acetate exerts its anti-androgenic effect through inhibiting the association of androgen with cytosolic receptors and preventing the nuclear retention of androgen-receptor complexes (Belham \& Neal, 1971; Peets, Henson \& Neri, 1974). A cytosolic receptor which after binding testosterone, is translocated to the nucleus is present in rat granulosa cells (Schreiber \& Ross, 1976). The present finding, that cyproterone acetate inhibits testosteronestimulated inhibin production, suggests that a similar cytosolic testosterone receptor capable of nuclear translocation may be present in bovine granulosa cells, and that receptors of this type may mediate androgenic stimulation of granulosa cell inhibin production. Cyproterone acetate also inhibited basal inhibin production by granulosa cells (Table 2), thereby implicating androgen involvement in this process. Bovine granulosa cells isolated from antral follicles contain appreciable amounts of endogenous testosterone, in the order of $0 \cdot 2-10 \mathrm{ng} / \mathrm{mg}$ protein (Henderson \& Moon, 1979). The culture medium also contained small amounts of testosterone $(<20 \mathrm{pg} / \mathrm{ml})$ derived from the calf-serum. Together these small amounts of testosterone may be responsible, at least in part, for basal inhibin production by granulosa cells, and it is through blocking the action of this androgen that cyproterone acetate exerts its inhibitory effect on basal inhibin production. Bovine granulosa cells have only a very limited ability, if any, to synthesize androgens (Lacroix $e t$ al., 1974; Henderson \& Swanston, 1978). It is therefore tempting to speculate that follicular inhibin production may involve a co-operative interaction between theca and granulosa cells similar to that proposed for follicular oestradiol-17 3 production (Armstrong \& Dorrington, 1977) with thecal cellderived androgen being utilized to stimulate inhibin production by granulosa cells.

In addition to its effect on inhibin production, cyproterone acetate inhibited progesterone production by cultured follicular tissue and granulosa cells (Table 2). Oestradiol-17 $\beta$ production was unaffected. Androgens have previously been implicated in the regulation of granulosa cell progesterone production. In vitro, androgens stimulate progesterone production by cultured granulosa cells from immature, hypophysectomized oestrogen-treated rats (Lucky, Schreiber, Hillier, Schulman \& Ross, 1977; Nimrod, Rosenfield \& Otto, 1980), an effect which can be inhibited by cyproterone acetate and other anti-androgens (Hillier, Knazek \& Ross, 1977). In vivo, intra-ovarian implants of the anti-androgen, flutamide, reduce the ability of porcine granulosa cells to secrete progesterone in vitro (Schomberg, Williams, Tyrey \& Ulberg, 1978). While androgens failed to stimulate progesterone production by bovine follicular tissue and granulosa cells in this and other studies (Henderson \& Moon, 1979; Henderson \& Franchimont, 1981), a role for androgens in regulating bovine follicular progesterone production is suggested by the inhibitory action of cyproterone acetate. It is unlikely that the reduction in inhibin production by granulosa cells after cyproterone acetate treatment occurs as a consequence of the fall in progesterone production or vice versa. Previous studies indicate that progesterone inhibits granulosa cell inhibin production (Henderson \& Franchimont, 1981) while purified preparations of inhibin inhibit granulosa cell progesterone production (Franchimont et al., 1981). 
The ability to stimulate granulosa cell inhibin production is not restricted to the natural androgens, but is mimicked by the synthetic androgens, methylestrenolone and mesterolone (Table 3 ), and the ability to stimulate inhibin production may be a general property of androgenic compounds. In addition, these studies with non-aromatizable synthetic androgens confirm the previous finding that the stimulatory effect of androgens on inhibin is direct and not dependent upon their aromatization to oestrogen (Henderson \& Franchimont, 1981). Androgen stimulation of inhibin production is probably, therefore, a receptor-mediated event.

The assigned molecular weight of inhibin is usually between 10000 and 30000 although inhibin activity has been reported in molecular weight fractions of $>100000$ and $<5000$ (Franchimont et al., 1979; de Jong, Jansen \& van der Molen, 1981). This inconsistency is probably due to (1) the different methods of measuring inhibin activity and determining molecular weight, (2) the fact that few of the studies have been performed with purified inhibin, and (3) because inhibin appears to be biochemically heterogeneous (Franchimont et al., 1979). The inhibin activity of bovine granulosa cell culture medium after ultrafiltration was only found in the $M_{r}>100000$ fraction. Using a similar ultrafiltration method, Cahoreau, Blanc, Dacheux, Pisselet \& Courot (1979) found the inhibin activity of ram rete testis fluid to be in the $M_{r}>100000$ fraction. It is possible, however, that the concentrating effect of ultrafiltration promotes aggregation of lower molecular weight forms. The loss of inhibin activity of bovine granulosa cell culture medium by heating to $80^{\circ} \mathrm{C}$ for 30 min is consistent with the finding that inhibin present in Sertoli cell culture medium (Steinberger \& Steinberger, 1976) and rete testis fluid (Franchimont et al., 1979) is also thermolabile.

We thank Dr K. P. McNatty, Wallaceville Animal Research Centre, New Zealand, for antisera to progesterone and oestradiol-17 $\beta$; NIAMDD, NIH, Bethesda, U.S.A., for rat gonadotrophin assay materials; Professor B. Hudson, Howard Florey Institute of Experimental Physiology and Medicine, Melbourne, Australia, for the reference preparation of inhibin; and Chantal CharletRenard for excellent technical assistance. This work was supported by Grant No. 3.4501.80 from the Belgian Foundation for Scientific Medical Research (F.R.S.M.). This study was performed while K.M.H. was in receipt of an Australian Queen Elizabeth II Research Fellowship and the paper prepared whilst in receipt of a New Zealand National Research Advisory Council Research Fellowship.

\section{References}

Anderson, L.D. \& de Paolo, L.V. (1981) Control of inhibin secretion from the ovary. In Intragonadal Regulation of Reproduction, pp, 343-363. Eds P. Franchimont \& C. P. Channing. Academic Press, London.

Armstrong, D.T. \& Dorrington, J.H. (1977) Estrogen biosynthesis in the ovaries and testes. In Regulatory Mechanisms Affecting Gonadal Hormone Action, vol. 3, pp. 217-258. Eds J. A. Thomas \& R. L. Singhal. University Park Press, Baltimore.

Belham, J.E. \& Neal, G.E. (1971) Testosterone action in the rat ventral prostate. Biochem. J. 125, 81-91.

Borth, R. (1976) Statistics of parallel-line assay. In Methods of Hormone Analysis, pp. 500-513. Eds H. Breuer, D. Hamel \& H. L. Kruskemper. George Thieme Verlag, Stuttgart.

Cahoreau, C., Blanc, M.R., Dacheux, J.L., Pisselet, C. \& Courot, M. (1979) Inhibin activity in ram rete testis fluid: depression of plasma FSH and LH in the castrated and cryptorchid ram. J. Reprod. Fert., Suppl. 26, 97-116.

de Jong, F.H., Jansen, E.H.J.M. \& van der Molen, H.J. (1981) Purification and characterization of inhibin.
In Intragonadal Regulation of Reproduction, pp. 229250. Eds P. Franchimont \& C. P. Channing. Academic Press, London.

Eagle, A. (1959) Amino acid metabolism in mammalian cell cultures. Science, N.Y. 130, 432-437.

Eddie, L.W., Baker, H.W.G., Higginson, R.E. \& Hudson, B. (1979) A bioassay for inhibin using pituitary cell cultures. J. Endocr. 81, 49-60.

Erickson, G.L. \& Hsueh, A.J.W. (1978) Secretion of inhibin by rat granulosa cells in vitro. Endocrinology 103, 1960-1963.

Franchimont, P., Verstraelen-Proyard, J., Hazee-Hagelstein, M.T., Charlet-Renard, C., Demoulin, A., Bourguignon, J.P. \& Hustin, J. (1979) Inhibin: from concept to reality. Vitams Horm. 37, 243-302.

Franchimont, P., Henderson, K., Verhoeven, G., HazeeHagelstein, M.T., Charlet-Renard, C., Demoulin, A., Bourguignon, J.P. \& Lecomte-Yerna, M.J. (1981) Inhibin: mechanisms of action and secretion. In Intragonadal Regulation of Reproduction, pp. 167-191. Eds P. Franchimont \& C. P. Channing. Academic Press, London. 
Henderson, K.M. \& Franchimont, P. (1981) Regulation of inhibin production by bovine ovarian cells in vitro. $J$. Reprod. Fert. 63, 431-442.

Henderson, K.M. \& Moon, Y.S. (1979) Luteinization of bovine granulosa cells and corpus luteum formation associated with loss of androgen aromatizing ability. J. Reprod. Fert. 56, 89-97.

Henderson, K.M. \& Swanston, I.A. (1978) Androgen aromatization by luteinized bovine granulosa cells in tissue culture. J. Reprod. Fert. 52, 131-134.

Hillier, S.G., Knazek, R.A. \& Ross, G.T. (1977) Androgenic stimulation of progesterone production by granulosa cells from preantral ovarian follicles: further in vitro studies using replicate cell culture. Endocrinology 100, 1539-1549.

Lacroix, E., Eechaute, W. \& Leusen, I. (1974) The biosynthesis of estrogens by cow follicles. Steroids 23 , 337-356.

Lowry, O.H., Rosebrough, N.J., Farr, A.L. \& Randall, R.S. (1951) Protein measurement with the Folin phenol reagent. J. biol. Chem. 193, 265-275.

Lucky, A.W., Schreiber, J.R., Hillier, S.G., Schulman, J.D. \& Ross, G.T. (1977) Progesterone production by cultured preantral rat granulosa cells: stimulation by androgens. Endocrinology 100, 128-133.

McNatty, K.P., Gibb, M., Dobson, C., Thurley, D.C. \& Findlay, J.K. (1981) Changes in the concentration of gonadotrophic and steroidal hormones in the antral fluid of ovarian follicles throughout the oestrous cycle of the ewe. Aust. J. biol. Sci. 34, 67-80.

Nimrod, A., Rosenfield, R.L. \& Otto, P. (1980) Relationship of androgen action to androgen metabolism in isolated rat granulosa cells. J. Steroid Biochem. 13, 1015-1019.

Patterson, M.K. (1979) Measurement of growth and viability of cells in culture. In Methods in Enzymology, vol. 58, pp. 141-152. Eds W. B. Jakoby \& I. H. Pastan. Academic Press, New York.

Peets, E.A., Henson, M.F. \& Neri, R. (1974) On the mechanism of the anti-androgenic action of flutamide ( $\alpha-\alpha-\alpha$-trifluoro-2-methyl-4-nitro-m-propionotoluidide) in the rat. Endocrinology 94, 532-540.

Schomberg, D.W., Williams, R.F., Tyrey, L. \& Ulberg, L.D. (1978) Reduction of granulosa cell progesterone secretion in vitro by intra-ovarian implants of antiandrogen. Endocrinology 102, 984-986.

Schreiber, J.R. \& Ross, G.T. (1976) Further characterization of a rat ovarian testosterone receptor with evidence for nuclear translocation. Endocrinology 99 , 590-596.

Steinberger, A. \& Steinberger, E. (1976) Secretion of an FSH-inhibiting factor by cultured sertoli cells. Endocrinology 99, 918-921.

Received 7 June 1982 